\title{
Effect of Processing and Drying Methods on the Nutritional Characteristic of the Multi-cereals and Legume Flour
}

\section{Kumari PV ${ }^{1 *}$ and Sangeetha $\mathbf{N}^{2}$}

$1 / I C P T$, Thanjavur, Tamilnadu, India

${ }^{2}$ Department of Food Science and Technology, Pondicherry University, Puducherry, India

\begin{abstract}
Cereals and legumes of today are more nutritious and healthful than ever before. Cereals and legumes processing is one of the oldest and the most essential part of all food technologies. Besides, it forms a large and indispensable component of the food production chain. The cereals and legume processing industry is as diverse as its range of products. Drying and dewatering plays an important role in food manufacturing and food processing activities worldwide often one of the last operations in the food processing. In this study three sets of ingredients were chosen they subject to different treatment and drying conditions. The results found that significant difference was observed in the nutritional composition of different treatment and different drying conditions. The developed composite mix has possessed to have good nutritional properties and it possess o have good health benefits. This mix can be used for further product development.
\end{abstract}

Keywords: Cereals; Legumes; Drying; Germination; Milling

\section{Introduction}

The consumer demand for nutritious cereal-based food products with minimal artificial additives has been met with increased research and development from the food industry. Nutritional quality is eventually important in considering processed flour as a food ingredient and its successful performance depends principally on functional characteristics imparted to the final products. The versatility of processed flour as a base for many food products emphasizes the need for a better understanding of its functional characteristics and nutritional characteristics of the processed flour [1]. Composite flours containing cereal and legumes have proven practical uses in many parts of the world to improve the nutritional and functional properties of flour. Basically, composite flour technology refers to the process of mixing wheat flour with cereals or legumes to make use of indigenous raw materials to produce high quality food products in an economical way. Being nutridense, these formulations could form sustainable strategy for combating malnutrition [2]. One of the chief challenges of nutritionists is to diminish human sufferings due to nutritional stress as Indian population suffers from food and nutritional insecurity. Hence the present study was carried out with object to study the nutrition characteristics of the multi cereal and legume mix subjected to different drying methods.

\section{Materials and Methods}

\section{Selection of raw materials}

The whole cereals and legumes with immense nutritional potentiality were selected for the formulation of processed multi-cereals and legume flour. The good quality raw materials were purchased from the wholesale shop in bulk quantity to maintain uniform quality throughout the processing. The selected raw materials are listed in Table 1.

\section{Steps involved in the formulation of processed multi-cereals and legume flour from 3 sets of raw materials}

The selected raw materials were washed to remove the unwanted dust particles. The listed sets (Table 1) were weighed and soaked in water for a period of $12 \mathrm{~h}$, after which the excess water was drained and each set was divided in two groups. Group A was allowed to sprout for

\begin{tabular}{|c|c|c|c|}
\hline $\begin{array}{c}\text { Set } 1 \\
\text { (Cereals) }\end{array}$ & $\begin{array}{c}\text { Set } 2 \\
\text { (Legumes) }\end{array}$ & $\begin{array}{c}\text { Set } 3 \\
\text { (Cereals and Legumes) }\end{array}$ & $\begin{array}{c}\text { Quantity } \\
(\%)\end{array}$ \\
\hline $\begin{array}{l}\text { Parboiled rice } \\
\text { (Oryza punctata) }\end{array}$ & $\begin{array}{c}\text { Dry peas } \\
\text { (Pisum sativum) }\end{array}$ & $\begin{array}{l}\text { Parboiled rice } \\
\text { (Oryza punctata) }\end{array}$ & 20 \\
\hline $\begin{array}{l}\text { Kodo millet } \\
\text { (Paspalum } \\
\text { scrobiculatum) }\end{array}$ & $\begin{array}{c}\text { Red Gram } \\
\text { ( Cajanus cajan) }\end{array}$ & $\begin{array}{l}\text { Kodo millet } \\
\text { (Paspalum } \\
\text { scrobiculatum) }\end{array}$ & 10 \\
\hline $\begin{array}{c}\text { Sorghum } \\
\text { (Sorghum bicolor) }\end{array}$ & $\begin{array}{c}\text { Rajma } \\
\text { (Phaseolus vulgaris) }\end{array}$ & $\begin{array}{c}\text { Sorghum } \\
\text { (Sorghum bicolor) }\end{array}$ & 10 \\
\hline $\begin{array}{l}\text { Foxtail millet } \\
\text { (Setaria italica) }\end{array}$ & $\begin{array}{l}\text { Horse gram } \\
\text { (Macrotyloma } \\
\text { uniflorum) }\end{array}$ & $\begin{array}{l}\text { Foxtail millet } \\
\text { (Setaria italica) }\end{array}$ & 10 \\
\hline $\begin{array}{c}\text { Oats } \\
\text { (Avena sativa) }\end{array}$ & $\begin{array}{l}\text { Green gram } \\
\text { (Vigna radiata) }\end{array}$ & $\begin{array}{l}\text { Green gram } \\
\text { (Vigna radiata) }\end{array}$ & 10 \\
\hline $\begin{array}{c}\text { Maize } \\
\text { (Zea mays) }\end{array}$ & $\begin{array}{c}\text { Bengal gram } \\
\text { (Cicer arietinum) }\end{array}$ & $\begin{array}{c}\text { Bengal gram } \\
\text { (Cicer arietinum) }\end{array}$ & 10 \\
\hline $\begin{array}{c}\text { Barley } \\
\text { (Hordeum vulgare) }\end{array}$ & $\begin{array}{c}\text { Black gram } \\
\text { (Vigna mungo) }\end{array}$ & $\begin{array}{c}\text { Black gram } \\
\text { (Vigna mungo) }\end{array}$ & 10 \\
\hline $\begin{array}{c}\text { Wheat } \\
\text { (Triticum aestivum) }\end{array}$ & $\begin{array}{c}\text { Cow pea } \\
\text { (Vigna unguiculata) }\end{array}$ & $\begin{array}{c}\text { Cow pea } \\
\text { (Vigna unguiculata) }\end{array}$ & 10 \\
\hline $\begin{array}{c}\text { Bajra } \\
\text { (Pennisetum } \\
\text { glaucum) }\end{array}$ & $\begin{array}{l}\text { Soyabean } \\
\text { (Glycine max) }\end{array}$ & $\begin{array}{l}\text { Soyabean } \\
\text { (Glycine max) }\end{array}$ & 10 \\
\hline
\end{tabular}

Table 1: Raw materials selected for processing and product development.

a period of $24 \mathrm{~h}$ and the group B was not sprouted. The processed raw materials were subjected to drying methods namely sun drying (SD for $12 \mathrm{~h}$ ), forced convection tray drying (FCTD at $60^{\circ} \mathrm{C}$ for $8 \mathrm{~h}$ ) and fluidized bed drying $\left(\mathrm{FBD}\right.$ at $60^{\circ} \mathrm{C}$ for $6 \mathrm{~h}$ ). All the dried raw materials were milled in stone miller to obtain fine flour. The process involved in the formulation of multi-cereal and legume flour from 3 sets of raw materials is shown in Figure 1.

*Corresponding author: Kumari PV, IICPT, Thanjavur, Tamilnadu, India, Tel: 04362-228155; E-mail: Vasanthi.phd@gmail.com

Received March 10, 2017; Accepted March 29, 2017; Published April 05, 2017

Citation: Kumari PV, Sangeetha N (2017) Effect of Processing and Drying Methods on the Nutritional Characteristic of the Multi-cereals and Legume Flour. J Food Process Technol 8: 667. doi: 10.4172/2157-7110.1000667

Copyright: (c) 2017 Kumari PV, et al. This is an open-access article distributed under the terms of the Creative Commons Attribution License, which permits unrestricted use, distribution, and reproduction in any medium, provided the original author and source are credited. 
Citation: Kumari PV, Sangeetha N (2017) Effect of Processing and Drying Methods on the Nutritional Characteristic of the Multi-cereals and Legume Flour. J Food Process Technol 8: 667. doi: 10.4172/2157-7110.1000667

Page 2 of 5

\section{Chemical composition}

The chemical composition of the cereal and legume mix namely carbohydrate [3] proteins [4] fats [5] energy [6] moisture [7] and ash were carried out using standard procedure. Carbohydrate by anthrone method, protein by the kjeldhal method with (NX6.25), fat by soxlet method with automated soxpluse, energy using boam calorimeter, moisture determined by hot air oven method and ash using muffle furnance.

\section{Results and Discussion}

\section{Carbohydrate $(\mathrm{g} / 100 \mathrm{~g})$ content of the multi-cereals and legume flour}

Carbohydrates are the macronutrient which plays a major role in human diets, comprising $40 \%$ to $75 \%$ of energy intake. Their most important nutritional property is digestibility in the small intestine. In terms of their physiological or nutritional role, they are often classified as available and unavailable carbohydrates (Table 2). The carbohydrate content of the multi-cereals and legume flour were found to be in the range of $46.66 \mathrm{~g} / 100 \mathrm{~g}$ to $67.33 \mathrm{~g} / 100 \mathrm{~g}$ in the non-sprouted sets subjected to sun drying, where as in the sprouted sets subjected to sun drying was found to be in the range of $36 \mathrm{~g} / 100 \mathrm{~g}$ to $2 \mathrm{~g} / 100 \mathrm{~g}$. In the case of fluidized bed drying, the carbohydrate content of the non- sprouted sets was found to be in the range of $43.66 \mathrm{~g} / 100 \mathrm{~g}$ to $65.33 \mathrm{~g} / 100 \mathrm{~g}$ and 34 $\mathrm{g} / 100 \mathrm{~g}$ to $51.66 \mathrm{~g} / 100 \mathrm{~g}$ in the sprouted samples of all the three sets. As

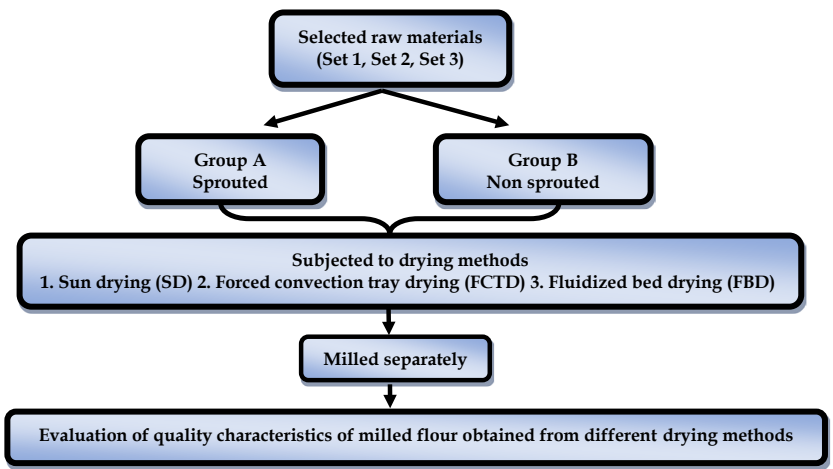

Figure 1: Processed involved in the formulation of processed multicereals and legume flour from 3 sets of raw materials.

\begin{tabular}{|c|c|c|c|c|}
\hline $\begin{array}{l}\text { Processing } \\
\text { methods }\end{array}$ & Sets & SD & FBD & FCTD \\
\hline \multirow{3}{*}{ NS } & Set 1 & $67.33 \pm 2.08$ & $65.33 \pm 1.52$ & $64.66 \pm 2.51$ \\
\hline & Set 2 & $46.66 \pm 1.52$ & $43.66 \pm 1.52$ & $41.66 \pm 2.08$ \\
\hline & Set 3 & $52.66 \pm 2.51$ & $51.66 \pm 1.52$ & $48.66 \pm 1.52$ \\
\hline \multirow{3}{*}{ SP } & Set 1 & $52.00 \pm 2.00$ & $51.66 \pm 1.52$ & $52.66 \pm 1.52$ \\
\hline & Set 2 & $36.00 \pm 1.00$ & $34.00 \pm 2.00$ & $34.00 \pm 2.00$ \\
\hline & Set 3 & $50.00 \pm 1.00$ & $45.66 \pm 2.08$ & $44.00 \pm 1.00$ \\
\hline \multirow{3}{*}{$\mathrm{p}$-value } & Drying methods & \multirow{3}{*}{\multicolumn{3}{|c|}{$P \leq 0.05^{*}$}} \\
\hline & $\begin{array}{l}\text { Processing } \\
\text { methods }\end{array}$ & & & \\
\hline & Sets & & & \\
\hline
\end{tabular}

All values are means of triplicate determinations \pm Standard Deviation (S.D) NS: Non-Sprouted; SP: Sprouted: SD: Sun Drying; FBD: Fluidized Bed Drying; FCTD: Forced Convection Tray Drying; Set 1: Cereals; Set 2: Legumes; Set 3: Cereals and Legumes

*Significantly different $(p \leq 0.05)$ by ANOVA

Table 2: Carbohydrate $(\mathrm{g} / 100 \mathrm{~g})$ content of the multi-cereals and legume flour.

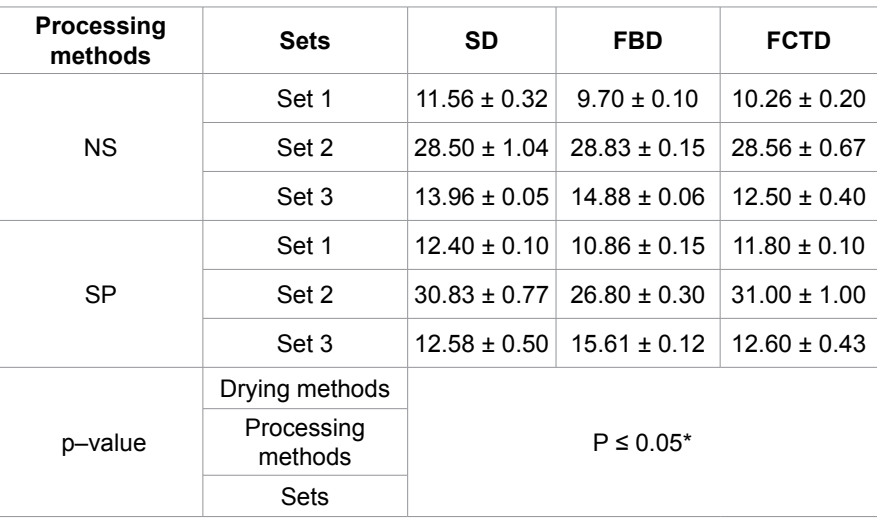

All values are means of triplicate determinations \pm Standard Deviation (S.D)

NS: Non-Sprouted; SP: Sprouted: SD: Sun Drying; FBD: Fluidized Bed Drying; FCTD: Forced Convection Tray Drying; Set 1: Cereals; Set 2: Legumes; Set 3: Cereals and Legumes

*Significantly different $(p \leq 0.05)$ by ANOVA

Table 3: Protein $(\mathrm{g} / 100 \mathrm{~g})$ content of the multi-cereals and legume flour.

far as the forced convection tray drying is concerned, the carbohydrate content of non-sprouted and sprouted sets was in the range of 41.66 $\mathrm{g} / 100 \mathrm{~g}$ to $64.66 \mathrm{~g} / 100 \mathrm{~g}$ and $34 \mathrm{~g} / 100 \mathrm{~g}$ to $52.66 \mathrm{~g} / 100 \mathrm{~g}$ respectively. The sprouted samples of all the three sets showed a significant decrease in the carbohydrate content when compared to samples which was not allowed for sprouting. The set 1 which constitute the cereals resulted in increased carbohydrate content. The concentration of carbohydrate in the samples exposed to different drying methods was almost similar and slightly higher in sun dried sample which was found to be statistically significant $(p \leq 0.05)$. Vidal-Valverde et al. [8] explained that during germination, carbohydrate was used as source of energy for embryonic growth which could explain the changes of carbohydrate content after germination. The findings of the carbohydrate content of the multicereals and legume flour was in par with results of Khetarpaul and Goyal [9] who reported that during germination, mobilization and hydrolysis of seed polysaccharides takes place. Polysaccharides can promote hydrolysis by fermenting microbes which possess both alpha and beta amylases [10]. A sharp decrease in total and reducing sugar at $48 \mathrm{hrs}$ may be due to microbial utilization.

\section{Protein (g/100 g) content of multi-cereals and legume flour}

Cereal grains and legumes are a valuable source of food proteins. In comparison to cereal grains, the seeds of legumes are rich in good quality protein, providing man with a highly nutritious food resource. Similarly, in the present study, the protein content in both the processing methods adopted was found to be considerably ( $\mathrm{p} \leq$ 0.05 ) high especially in set 2 comprising of legumes. The increase in the protein content is due to presence of whole legumes. The protein content of the sets subjected to sprouting and non-sprouting which are exposed to sun drying was in the range of $12.40 \mathrm{~g} / 100 \mathrm{~g}$ to $30.83 \mathrm{~g} / 100$ $\mathrm{g}$ and $11.56 \mathrm{~g} / 100 \mathrm{~g}$ to $28.50 \mathrm{~g} / 100 \mathrm{~g}$ respectively. In the case of nonsprouted and sprouted sets dried using fluidized bed drying the protein content was found to be in the range of $14.88 \mathrm{~g} / 100 \mathrm{~g}$ to $28.83 \mathrm{~g} / 100 \mathrm{~g}$ and $10.86 \mathrm{~g} / 100 \mathrm{~g}$ to $26.80 \mathrm{~g} / 100 \mathrm{~g}$ respectively (Table 3 ). As far as the protein content of non-sprouted and sprouted samples in all the three sets exposed to forced convection tray drying are concerned, the values were in the range of $10.26 \mathrm{~g} / 100 \mathrm{~g}$ to $28.56 \mathrm{~g} / 100 \mathrm{~g}$ and $11.80 \mathrm{~g} / 100$ $\mathrm{g}$ to $31.00 \mathrm{~g} / 100 \mathrm{~g}$ respectively. Grain legumes enhance the protein content of cereal-based diets and may improve the nutritional status as well. Cereal proteins are deficient in certain essential amino acids, particularly lysine [11]. On the other hand, legumes have been reported 
to contain adequate amounts of lysine, but are deficient in S-containing amino acids (methionine, cystine and cysteine) [12]. Chavan and Kadam [13] stated that complex qualitative changes are reported to occur during soaking and sprouting of seeds. The conversion of storage proteins of cereal grains into albumins and globulins during sprouting may improve the quality of cereal proteins. Many studies have shown an increase in the content of the amino acid lysine upon sprouting. Increase in proteolytic activity during sprouting is desirable for nutritional improvement of cereals because it leads to hydrolysis of prolamins and the liberation of amino acids such as glutamine and proline which are converted to limiting amino acids such as lysine.

\section{Fat $(\mathrm{g} / 100 \mathrm{~g})$ content of multi-cereal and legume flour}

Generally, cereals and legumes are low in fat. The fat composition was notably ( $p \leq 0.05$ ) less in all the sprouted samples, since the fat was used as source of energy during germination. The fat content in the non-sprouted and sprouted samples of all the three sets subjected to different drying methods was found to be in range of $3.36 \mathrm{~g} / 100 \mathrm{~g}$ to $3.50 \mathrm{~g} / 100 \mathrm{~g}$ and $1.16 \mathrm{~g} / 100 \mathrm{~g}$ to $2.76 \mathrm{~g} / 100 \mathrm{~g}$ in the non-sprouted and sprouted sets subjected to sun drying; $1.63 \mathrm{~g} / 100 \mathrm{~g}$ to $3.43 \mathrm{~g} / 100$ $\mathrm{g}$ and $0.90 \mathrm{~g} / 100 \mathrm{~g}$ to $2.66 \mathrm{~g} / 100 \mathrm{~g}$ in the non-sprouted and sprouted sets subjected to fluidized bed drying; $1.90-3.10 \mathrm{~g} / 100 \mathrm{~g}$ and $1.10 \mathrm{~g} / 100$ $\mathrm{g}$ to $2.40 \mathrm{~g} / 100 \mathrm{~g}$ in the non-sprouted and sprouted sets subjected to forced convection tray drying respectively (Table 4). On germination, there existed a significant $(\mathrm{p} \leq 0.05)$ decrease of fat content in three sets

\begin{tabular}{|c|c|c|c|c|}
\hline $\begin{array}{l}\text { Processing } \\
\text { methods }\end{array}$ & Sets & SD & FBD & FCTD \\
\hline \multirow{3}{*}{ NS } & Set 1 & $2.66 \pm 0.15$ & $1.63 \pm 0.20$ & $1.90 \pm 0.10$ \\
\hline & Set 2 & $3.50 \pm 0.20$ & $3.43 \pm 0.25$ & $3.10 \pm 0.10$ \\
\hline & Set 3 & $3.36 \pm 0.30$ & $3.40 \pm 0.20$ & $2.86 \pm 0.15$ \\
\hline \multirow{3}{*}{ SP } & Set 1 & $1.16 \pm 0.15$ & $0.90 \pm 0.10$ & $1.10 \pm 0.10$ \\
\hline & Set 2 & $2.50 \pm 0.20$ & $2.16 \pm 0.15$ & $2.40 \pm 0.30$ \\
\hline & Set 3 & $2.76 \pm 0.15$ & $2.66 \pm 0.25$ & $1.53 \pm 0.25$ \\
\hline \multirow{3}{*}{ p-value } & Drying methods & \multirow{3}{*}{\multicolumn{3}{|c|}{$P \leq 0.05^{*}$}} \\
\hline & Processing methods & & & \\
\hline & Sets & & & \\
\hline
\end{tabular}

All values are means of triplicate determinations \pm Standard Deviation (S.D) NS: Non-Sprouted; SP: Sprouted: SD: Sun Drying; FBD: Fluidized Bed Drying; FCTD: Forced Convection Tray Drying; Set 1: Cereals; Set 2: Legumes; Set 3: Cereals and Legumes

*Significantly different $(p \leq 0.05)$ by ANOVA

Table 4: Fat $(\mathrm{g} / 100 \mathrm{~g})$ content of the multicereals and legume flour.

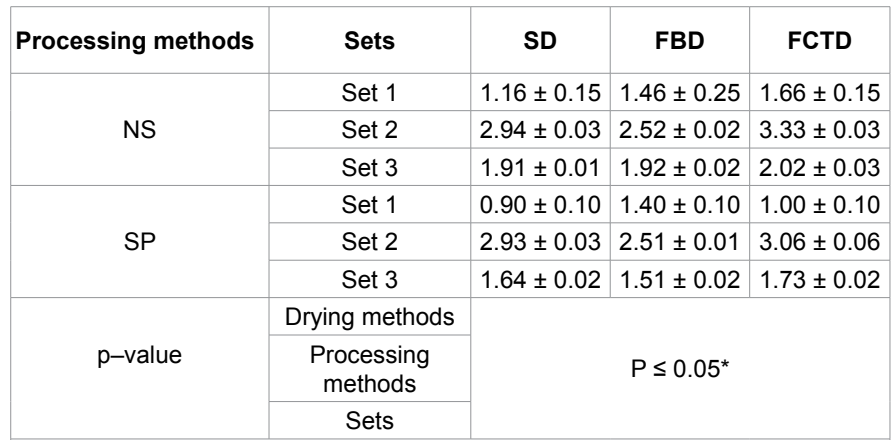

All values are means of triplicate determinations \pm Standard Deviation (S.D) NS: Non-Sprouted; SP: Sprouted: SD: Sun Drying; FBD: Fluidized Bed Drying; FCTD: Forced Convection Tray Drying; Set 1: Cereals; Set 2: Legumes; Set 3: Cereals and Legumes

*Significantly different $(p \leq 0.05)$ by ANOVA

Table 5: Ash (g/100 g) content of the multicereals and legume flour.

\begin{tabular}{|c|c|c|c|c|}
\hline Processing methods & Sets & SD & FBD & FCTD \\
\hline \multirow{3}{*}{ NS } & Set 1 & $303 \pm 2.51$ & $295 \pm 3.05$ & $292 \pm 2.51$ \\
\hline & Set 2 & $334 \pm 2.51$ & $312 \pm 2.08$ & $325 \pm 2.00$ \\
\hline & Set 3 & $311 \pm 2.00$ & $287 \pm 2.51$ & $293 \pm 3.60$ \\
\hline \multirow{3}{*}{ SP } & Set 1 & $283 \pm 1.52$ & $291 \pm 2.08$ & $273 \pm 1.52$ \\
\hline & Set 2 & $306 \pm 3.05$ & $304 \pm 3.60$ & $295 \pm 2.51$ \\
\hline & Set 3 & $294 \pm 3.51$ & $270 \pm 1.52$ & $271 \pm 1.00$ \\
\hline \multirow{3}{*}{$p$-value } & Drying methods & \multirow{3}{*}{\multicolumn{3}{|c|}{$P \leq 0.05^{*}$}} \\
\hline & $\begin{array}{l}\text { Processing } \\
\text { methods }\end{array}$ & & & \\
\hline & Sets & & & \\
\hline
\end{tabular}

All values are means of triplicate determinations \pm Standard Deviation (S.D) NS: Non-Sprouted; SP: Sprouted: SD: Sun Drying; FBD: Fluidized Bed Drying; FCTD: Forced Convection Tray Drying; Set 1: Cereals; Set 2: Legumes; Set 3 : Cereals and Legumes

*Significantly different $(p \leq 0.05)$ by ANOVA

Table 6: Energy (Kcal/100 g) value of the multi-cereals and legume flour.

subjected to different drying methods, which could be due to total solid loss during soaking prior to germination [14] or use of fat as an energy source in sprouting process. The results are comparable with findings of Vanderstoep [15] for germinated green gram and lentil.

\section{Ash $(\mathrm{g} / 100 \mathrm{~g})$ content of multi-cereals and legume flour}

Ash is the inorganic residue remaining after the water and organic matter have been removed by heating in the presence of oxidizing agents, which provides a measure of the total amount of minerals within a food. The ash content of all the sets subjected to different drying methods did not vary much. The sprouted sets possess to have a slight decrease in the ash content which reflects on the concentration of minerals (Table 5). Increased ash content was observed among non-sprouted samples of all the three sets subjected to different drying techniques when compared to the sprouted sets exposed to different drying techniques. Leaching out of solid matter during pre-germination soaking process could be the reason for significant reduction of mineral matter on germination. The results are in par with the findings of Okrah [16] who found that ash content of germinated sorghum was decreased which varied from $0.28 \%$ to $1.70 \%$. While, Mubarak [17] reported that germination and cooking processes caused significant decreases in ash content. Alemu [18] observed that sorghum ash content was significantly decreased after fermentation.

\section{Energy (Kcal/100 g) value of multi-cereals and legume flour}

Calories are a measure of energy and are commonly used to describe the energy content of foods. The energy values (Kcal) represent the presence of complex mixture of carbohydrates, protein and fat. In the present study, there was no considerable difference $(\mathrm{p}>0.05)$ in the energy levels of set 1 , set 2 and set 3 . However, the energy level was significantly decreased in the sprouted samples when compared to the non-sprouted samples. Total metabolizable energy content was higher during sprouting resulted in decreased energy value after sprouting. In the present study, the energy value was found to be in the range of $303-311 \mathrm{Kcal} / 100 \mathrm{~g}$ in the non-sprouted sets subjected to sun drying whereas after sprouting the energy value was found to in the range of $283-306 \mathrm{Kcal} / 100 \mathrm{~g}$. The non-sprouted sets subjected to fluidized bed drying was in the range of $287-312 \mathrm{Kcal} / 100 \mathrm{~g}$ and the energy value was found to be in the range $270-304 \mathrm{Kcal} / 100 \mathrm{~g}$ in the sprouted sets. The energy value of all the three sets which was not allowed for sprouting and subjected to forced convection tray drying was in the range of 292$325 \mathrm{Kcal} / 100 \mathrm{~g}$ where as in the sprouted sets the energy value was in the range of 271-295 Kcal/100 g (Table 6). 


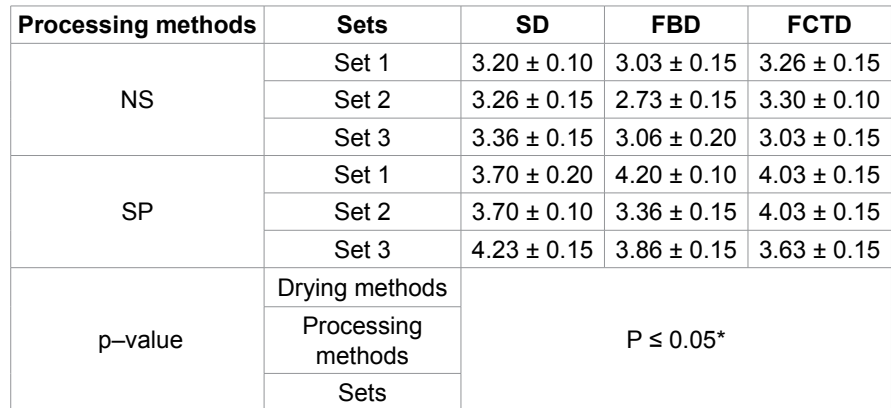

All values are means of triplicate determinations \pm Standard Deviation (S.D) NS: Non-Sprouted; SP: Sprouted: SD: Sun Drying; FBD: Fluidized Bed Drying; FCTD: Forced Convection Tray Drying; Set 1: Cereals; Set 2: Legumes; Set 3 : Cereals and Legumes

*Significantly different $(p \leq 0.05)$ by ANOVA

Table 7: Crude fiber ( $\mathrm{g} / 100 \mathrm{~g}$ ) content of the multicereals and legume flour.

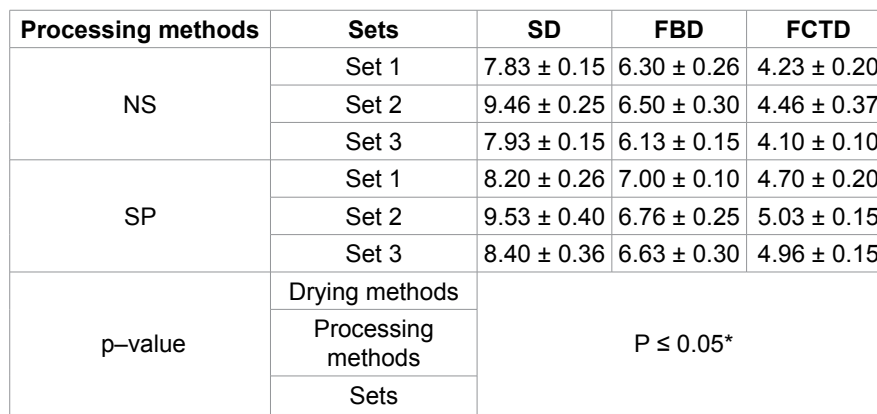

All values are means of triplicate determinations \pm Standard Deviation (S.D) NS: Non-Sprouted; SP: Sprouted: SD: Sun Drying; FBD: Fluidized Bed Drying; FCTD: Forced Convection Tray Drying; Set 1: Cereals; Set 2: Legumes; Set 3: Cereals and Legumes

*Significantly different $(\mathrm{p} \leq 0.05)$ by ANOVA

Table 8: Moisture $(\mathrm{g} / 100 \mathrm{~g})$ content of the multicereals and legume flour.

\section{Crude fiber $(\mathrm{g} / 100 \mathrm{~g})$ content of multi-cereals and legume flour}

Measurements of crude fiber are the only index of food fiber content available at the present time. However, crude fiber values reflect only a portion of the fiber present in food. Crude fiber has been reported to recover on the average $20 \%$ of the hemicelluloses, $10 \%$ to $50 \%$ of the lignin and $50 \%$ to $80 \%$ of the cellulose [19]. In the present study, significant difference was observed $(\mathrm{p} \leq 0.05)$ between all the sets which was sprouted and non-sprouted and subjected to three different types of drying. The results of the present study were in par with Martin Cabrejas et al. [20], who found that the fibre increased substantially during germination by about $100 \%$ in peas. This increase in fibre was reported to be mostly due to changes in the polysaccharides found in the cell wall such as cellulose, glucose and mannose, suggesting that the changes were due to an increase in the cellular structure of the plant during germination [20]. The fibre content of set 2 comprising of legumes was appreciably higher $(\mathrm{p} \leq 0.05)$ than the set 1 and set 2 (Table 7).

\section{Moisture $(\mathrm{g} / 100 \mathrm{~g})$ content of multi-cereals and legume flour}

Moisture is the integral part of the cereals and legumes. In the present study, the moisture content of multi-cereals and legumes exposed to sun drying was greater when compared to other two drying methods. However, investigations have shown that low moisture content of food samples is a desirable phenomenon, since the microbial activity is reduced [21]. Low moisture content in food samples increased the storage periods of the food products [22] while high moisture content in foods encourages microbial growth leading to spoilage of foods [23]. Moisture content of raw material affects gelatinization process and lower moisture content indicates better gelatinization process [24-26] and better gelatinization process results in better swelling of the extrudate (Table 8 ). In the present study, significant difference ( $\mathrm{p} \leq 0.05$ ) was observed in the moisture content of the sets exposed to different drying techniques. On comparing the different drying techniques, sets subjected to forced convection tray drying possessed less moisture content when compared to other two drying techniques. The overall observation showed that the sets subjected to sun drying had higher retention of moisture content which is not acceptable for the storage of foods for a longer duration of time.

\section{Conclusion}

Nutritional quality is eventually important in considering processed flour as a food ingredient and its successful performance depends principally on functional characteristics imparted to the final products. The developed composite mix has possessed to have good nutritional properties and it possess o have good health benefits. This mix can be used for further product development.

\section{References}

1. McWatters K, Holmes M (1979) Influence of moist heat on solubility and emulsification properties of soy and peanut flours. J Food Sci 44: 774-776.

2. Gahlawat P, Sehgal S (1994) Protein quality of weaning foods based on locally available cereal and pulse combination. Plant Food Human Nutri 46: 245-253.

3. AOAC (1995) Official Methods of Analysis. (16th edn) Association of officia analytical chemists, Arlington, VA, USA.

4. Raghuramulu N, Madhavan K, Kalyansundaram S (2014) Food analysis: A Manual of Laboratory.

5. Ranganna S (2005) Vitamins: Hand book of Analysis and Quality Control for fruit and vegetable products. (2nd edn) Tata McGraw Hill publishing Co. Ltd New Delhi.

6. AOAC (1990) Official methods of analysis. (15th edn), official analytical chemists, Arlington, VA, USA, 1990

7. AACC (2005) Approved methods of the AACC. American association of cerea chemists. (11th edn), St. Paul, MN.

8. Vidal-Valverde C, Frias J, Sierra I, Blazquez I, Lambein F, et al. (2002) New functional legume foods by germination: Effect on the nutritive value of beans lentils and peas. Europe Food Res Technol 215: 472-477.

9. Khetarpaul N, Goyal R (1995) Effect of germination and probiotic fermentation on $\mathrm{pH}$, titratable acidity, dietary fibre, $\beta$-Glucan and vitamin content of sorghum based food mixtures. J Nutri Food Sci 2: 2.

10. Bernfeld S (1962) On psychoanalytic training. Psychoanalytic Quarterly 31 453-482.

11. Iqbal A, Khalil IA, Shah H (2003) Nutritional yield and amino acid profile of rice protein as influenced by nitrogen fertilizer. Sarhad J Agri (Pakistan) 26: 1237-1245.

12. Farzana W, Khalil IA (1999) Protein quality of tropical food legumes. J Sci Technol 23: 13-19.

13. Chavan JK, Kadamn SS (1989) Nutritional improvement of cereals by sprouting Critical Review Food Sci Technol 28: 401-437.

14. Wang N, Lewis MJ, Brennan JG, Westby A (1997) Effect of processing methods on nutrients and anti-nutritional factors in cowpea. Food Chem 58: 59-68.

15. Vanderstoep $\mathrm{J}$ (1981) Effect of germination on the nutritive value of legumes. Food Technol 26: 3121-3125.

16. Okrah SG (2008) Screening of six local sorghum varieties for their malting and brewing qualities. Kwame Nkrumah University Science and Technology, Ghana.

17. Mubarak AE (2005) Nutritional composition and antinutritional factors of 
Citation: Kumari PV, Sangeetha N (2017) Effect of Processing and Drying Methods on the Nutritional Characteristic of the Multi-cereals and Legume Flour. J Food Process Technol 8: 667. doi: 10.4172/2157-7110.1000667

Page 5 of 5

mung bean seeds (Phaseolus aureus) as affected by some home traditional processes. Food Chem 89: 489-495.

18. Alemu MK (2009) The effect of natural fermentation on some anti-nutritional factors, minerals, proximate composition and sensory characteristics in sorghum based weaning food. University of Addis Ababa, Ethiopia.

19. Van Soest PJ, McQueen RW (1973) The chemistry and estimation of fibre. Proceeding Nutrition Society 32: 123-130.

20. Martín-Cabrejas MA, Ariza N, Esteban R, Mollá E, Waldron K, et al. (2003) Effect of germination on the carbohydrate composition of the dietary fiber of peas (Pisum sativum L.) J Agri Food Chem 51: 1254-1259.

21. Oyenuga VA (1968) Nigeria's foods and feeding stuffs. University Press, Nigerian University.
22. Alozie Y, Akpanabiatu MI, Eyong EU, Umoh IB, Alozie G (2009) Amino acid composition of Dioscorea dumetorum varieties. Pak J Nutri 8: 103-105.

23. Temple VJ, Badamosi EJ, Ladeji O, Solomon M (1996) Proximate chemica composition of three locally formulated complementary foods. West Africa $J$ Biol Sci 5: 134-143

24. Miller RC (1985) Low moisture extrusion: Effect of cooking moisture on product characteristics. J Food Sci 50: 249-253.

25. Santosa BAS, Sudaryono S, Widowati S (2005) Technology evaluation of flour instant popcorn and quality. J Penelitian Pascapanen Pertanian 2: 66-75.

26. Foubion JM, Hoseney RC, Seib PA (1982) Functions quality of grain components in extrusion. Cereal Food World 27: 212- 216. 